\title{
The Life Cycle of a Kentucky Cave Beetle, Ptomaphagus hirtus, (Coleoptera; Leiodidae; Catopinae)
}

\author{
by
}

\author{
Stewart B. PECK*
}

\section{INTRODUCTION}

Little information is available on the life cycles of most insects. For most insects, even the life cycle stages are not known. Even less is known about the duration and habits of the immature stages and how they are adapted for their mode of existence. Studies on the life cycles of cave invertebrates have dealt mostly with aquatic crustaceans (see Vandel (1965) for details of previous work).

For life cycles, the best studied group of terrestrial cave arthropods are the European bathysciine (Leiodidae; Catopinae), and European trechine (Carabidae) beetles (Deleurance-Glaçon 1963a, 1963b, 1964). For the Bathysciini, DeleuranceGlaçon documented an adaptive modification of both the larval morphology and the duration of each developmental stage in 22 species in 10 genera and three phyletic series in one of the five divisions of the tribe, and one species in another division. Although the studies on these 23 species represent only a small percentage of the total of the 581 Eurasian Bathysciini (compiled from Laneyrie 1967, 1969), they have probably revealed the major evolutionary trends in the adaptation and modification of the life cycles of these eyeless and wingless cave inhabitants.

The American Ptomaphagus beetles offer an additional opportunity to study the life cycle characteristics of a cave-adapted species. Of the some 50 species of Ptomaphagus known in North America, 12 species in the southeastern United States are known to be troglobitic (blind, wingless, depigmented, obligate caveinhabitants) (Peck, 1973).

Ptomaphagus (Adelops) hirtus Tellkampf, of the Mammoth Cave region of westcentral Kentucky, was the best known troglobitic catopid when this study was started. Its larval and pupal stages were known, and it had been shown that large populations of adults as well as larval beetles could be easily collected in a week or so from carrion or cheese baits placed in many caves (see references in Peck, 1963:82, and discussions on pp. 35 and 48).

\section{METHODS}

Because of the lack of literature on the keeping and rearing of Ptomaphagus cave beetles, an extensive description of the methodology of the study is needed.

*) Department of Biology, Carleton University, Ottawa, Ontario, Canada. 
A sample of 216 adult beetles of unknown age were captured at rotted pig liver bait stations in Whites Cave, Edmonson County, Kentucky in early September, 1967. These and their offspring were kept in the laboratory and observed until 1973, when the study was discontinued.

The beetles were collected in the cave with an aspirator and transported from the cave to the laboratory in plastic boxes floored with mud (from the native cave) packed firmly into the bottom of the box. The plastic boxes were carried in a cool ice-chest. In the laboratory the beetles were kept in constant temperature and humidity chambers in large "community cultures" and in smaller cultures singly or as male and female pairs. The community culture consisted of a $25 \mathrm{~cm}$ x $30 \mathrm{~cm}$ clear plastic box with a removable lid, smoothly floored with a 5-10 mm thickness of hard-packed mud from the beetles' native cave. Single and paired beetles were kept in $54 \mathrm{~mm}$ and $89 \mathrm{~mm}$ (inside diameter) disposable plastic petri dishes. These dishes were floored with either mud from the beetles' native cave, or with a hardened black mixture of equal parts of plaster of Paris and powdered wood charcoal; in the second case a lump of native soil was placed on the plaster-charcoal substrate.

The need for the use of clay soil from the cave in which the beetles were collected must be emphasized. Many early failures at raising individuals through the life cycle stages seem to be related to culture dishes with no soil or with clay soil from caves other than the one in which the beetle culture was collected. This observation is contrary to that of Deleurance-Glacon (1963a:9) because she found that the bathysciines were insensitive to different soils. However, Gounot (1967) has discovered an apparently close association between many troglobites and cave silts, possibly related to the microflora of the silts.

Culture dishes can be made by pressing cave soil smoothly into the bottom of the dish, or more easily, a thick mud slurry can be made, poured through a screen to remove rocks and clay lumps, and spooned into the dishes. Tapping the side of the dish causes the slurry to spread uniformly over the dish bottom. Drying the dishes at room temperature for a day, before placing beetles in them, usually solidifies the mud sufficiently for the beetles to walk on its surface. Lastly, the mud should be at least $4 \mathrm{~mm}$ thick to have sufficient water retention properties to protect the beetles from desiccation.

The clay or plaster-charcoal of the bottoms of the culture containers were kept moist, almost to saturation, with distilled water. The species was fed and thrived upon Fleishmans dry yeast, a few crumbs being added each day or so. Food was available at all times, with the excess occasionally removed to prevent fungus growths. If the cultures do not dry out, the beetles have the ability to withstand prolonged starvation. By sealing the edges of the culture dishes and boxes with masking tape, moisture loss could be prevented for at least four months. This was done when I was away for more than a week on field trips and I could not care for the cultures.

The culture dishes and boxes were kept in a refrigerator-incubator at $12.5^{\circ} \mathrm{C}( \pm$ $0.5^{\circ} \mathrm{C}$ ), the temperature I measured in the caves of the Mammoth Cave region of Kentucky, although Barr and Kuehne (1971) report the cave temperatures to be $13.6^{\circ} \mathrm{C}$. The entire bottom of the incubator was kept filled with a $10-20 \mathrm{~mm}$ deep 
pool of water to saturate the atmosphere. The incubators were dark inside except when opening them to remove the beetles for examination.

The cultures were checked, fed and watered at varying intervals from between once every day to once every week. Detailed data were collected on adults and developmental stages singly and in pairs. Each individual was assigned a number which was entered in a data book, and the number written on a sticker on the culture dish. For the population, no number was used for more than one individual regardless of the life stage it was in when the number was assigned. Eggs were isolated within 24 hours of being laid and immature stages were kept and observed singly. Males and females were kept and observed singly or as pairs.

Daily observations of the beetles allowed detection of the daily changes such as day of first and subsequent egg laying, egg hatching, larval moulting, pupation, eclosion of pupa, etc. For determination of adult longevity and reproductive rates, the beetle pairs were generally examined at weekly intervals, and the larvae that had hatched in that week were counted, the number recorded, and the larvae removed from that dish. Bias from counting eggs will result because some or many of the eggs may be infertile. To determine the duration of each instar, the larvae at first were anaesthetized daily with $\mathrm{CO}_{2}$ and the head capsule width measured with an occular micrometer. Each increase in width was taken to signal a moult within the past 24 hours. However, this process undoubtedly disturbs the larvae and may introduce an experimental error. I later found that the shed larval skins were conspicuous enough to be observed, marking that a moult had occurred in the previous 24 hours.

\section{RESULTS}

Preliminary observations: Initial results of attempting to culture the beetles were discouraging until the importance of the substrate was discovered. That the presence of soil is necessary for larval survival was demonstrated by a group of $46 P$. hirtus larvae. These were kept in individual charcoalplaster bottomed dishes. Only five pupated, and three became adults, living only for a short time. The control was provided by later culture dishes, with native soil, from which an estimated $95 \%$ of all larvae became reproducing adults. For maturation and reproductive success, I found that no more than a small piece of native soil ( $5 \mathrm{~mm}$ square and $2 \mathrm{~mm}$ thick) was needed in a charcoal-plaster substrate dish. I do not know if the need exists throughout the life cycle, or for only a part of it.

The dependency upon native soil is based upon a presumed requirement for a heat-labile, biological component of the soil. This was assumed from the results of a group of $38 P$. hirtuss larvae placed in dishes with native soil that had been autoclaved. Of these 38 larvae, 29 lived to pupation, and 20 emerged as adults, but of these 20 , only one lived for more than a month.

The above observations, and similar results with several species of troglobitic Ptomaphagus from Alabama, indicate that each population may adjust to and be dependent upon a particular single or multiple factor in the soil of each popula- 
tion's cave. The soil-factor is biological in nature and is destroyed by autoclaving. It may well be a microbiological organism or byproduct. The problem is open for future research to anyone with a microbiological inclination.

In addition to a dependency on soil from a native cave, other difficulties became apparent that may affect the success of future cave beetle life cycle studies. 1) Several populations seemed to contract a contagious fungal disease that killed individuals in all developmental stages, or only as adults. 2) Half way through the study, predatory mites (Acridae, Caloglyphus mycophagus (Megnin), a stored products pest, H. H. J. Nesbitt determination), appeared in the incubators. These mites took a considerable toll of individuals of the cultures. Predation was most prevalent on the pupae, and sometimes on pre-pupal larvae. Eggs and adults did not seem to be bothered by the mites. Once the mites infested the incubators, it became nearly impossible to keep them from entering every culture dish, even after the dishes were ringed with vaseline. 3) Such life cycle studies as these which involve the duration of lengthy immature and adult stages are an insatiable mistress. They must receive attention at 24 hours intervals. The field oriented investigator will thus be kept from any travel which takes him away from the cultures for more than a day, or he will lose information. If a day is missed, and an individual beetle passes into the next life cycle stage, the investigator does not know in which 24 hour period the event occurred and loses both the date of the day of termination of the previous stage and the day of the beginning of the next stage.

Detailed Results: No precopulatory courtship was observed. Males, upon encountering females, instantly mounted and copulated. During copulation the males sometimes antennated the females, and the females always flexed downward at the pronotal-elytral junction, elevating the abdominal tip toward the males. Copulation was usually accomplished in 30 to 45 seconds. On one occasion a female copulated a second time 30 seconds after completion of the first. It is not known if the same or a different male was involved. No copulatory seasonality or cycle was noted.

Eggs were laid singly and at apparently random locations on the surface of the substrate. The females coated each egg with soil particles and debris as it was being laid. The soil and debris was gathered with the palps and mandibles, and was applied to the egg with the protarsi. When cleaned with a fine brush, the eggs were found to be smooth surfaced, whitish in color, and oval, with lengths averaging 0.74 $\mathrm{mm}$ and widths of about $0.58 \mathrm{~mm}$ (from a measured sample of 9). During their development, egg sizes increase somewhat through the uptake of water. The mean time for egg hatching is 18.5 days (table 1 ).

The life cycle characteristics of the larvae (table 1) were obtained from two sets of larvae. A set of 25 larvae on untreated Whites Cave soil (yielding the data in the column headed "instars", "feeding", and "in pupal cell") had mean spans for the first, second and third instars of $8.5,9.4$, and 39 days respectively. These figures yield a mean sum of 56.9 days for the combined larval instars. This sum compares acceptably with the sum of 52.5 days obtained from the mean of 27.2 days as a feeding larva plus 15.3 days as a third instar pupal cell larva. In a second set of 35 larvae on autoclaved Whites Cave soil (used to obtain the data in the column headed "total"), the combined length of the larval stages was 42 days. 


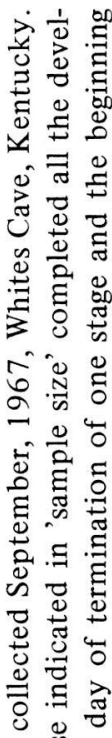

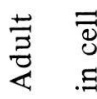

$m$ m m

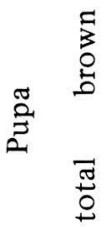

$\ddot{m} \quad \stackrel{0}{i}=\stackrel{\sim}{\sim}$

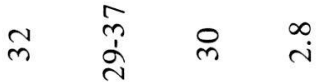

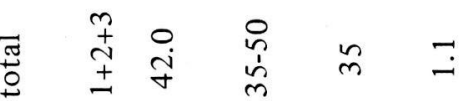

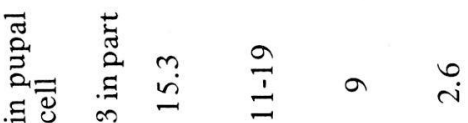

突

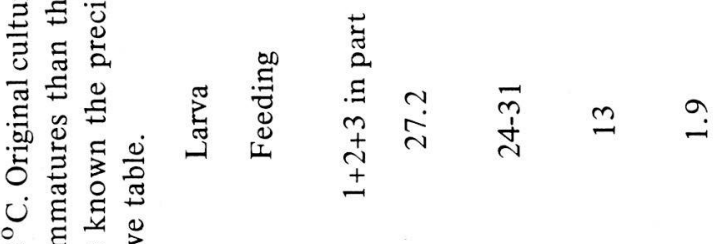

in $\Xi$.

용

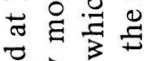

兽密宫点

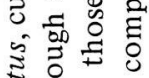

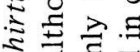

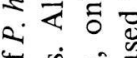

in के

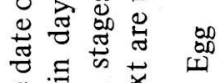

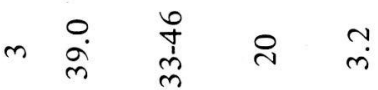

0.

范苛

ठิ

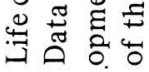

峁

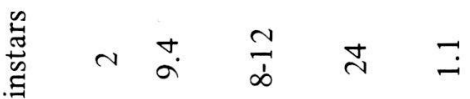

$-\infty \frac{m}{\pi} \approx m$

$\stackrel{\sim}{\infty} \stackrel{\sim}{\sim} \stackrel{\sim}{\sim}$

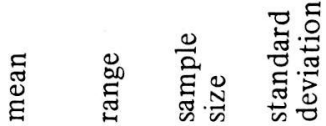


The two sets of larvae were differently treated, and the data gained for the two groups was separately recorded and evaluated, and is separately presented (table 1) in the different columns indicated above. The difference of 14.9 days between the means of 56.9 days and 42.0 days for the two samples of total larval life cannot now be positively explained, but I judge the two sets of data to be worth presenting. In retrospect, it seems likely that the development of the first set was delayed by the daily short term $\mathrm{CO}_{2}$ anaesthesia while their head capsule widths were being measured. It seems unlikely that the autoclaved substrate of the second set of larvae which were not anaesthetized would have had their development time speeded up. Therefore, the data in the "total" column for larval development is probably more reliable than that in the other colums on larval development.

The mean duration of the pupal stage (table 1) is 32 days, with the white pupae becoming noticeably brown in the last 3.3 days of pupation. The adult beetles remained in the pupal cell for a mean of 8.3 days before making a hole in the chamber wall and emerging.

In summary, a span of three to three and one half months is spent in the immature stages of egg, larva, and pupa in the laboratory. This figure is probably the minimum which may be attained under natural conditions in caves when food and moisture are sufficiently plentiful. How food or moisture inadequacies affect development times is not known.

Adult longevity of the beetles in caves is not known, but laboratory cultures showed life spans of several years when the beetles had abundant access to food, and protection from predation. Tables 2 and 3 present data on adult longevity and reproductive characteristics.

In a series of 10 adult females $(2 \mathrm{a}-20 \mathrm{a}$ in table 2$)$ captured in September, 1967 and kept in pairs with males, nine died within a year, and the last died after 767 days (2.1 years) of culture. The mean life span for nine of these females was 358 days. A series of 10 males kept in pairs with females, captured as adults (1a 19a in table 3), showed markedly longer life spans. Three died within 400 days of capture, three died within 700 days, one died 2.5 years later, and two males died 2.9 and 3.0 years after capture. The mean life span of six of these males was 674 days (1.8 years). Only individuals with precise death dates are used in these calculations.

Few data are available on complete adult longevity starting at the date of emergence from the pupa. For 10 females kept in pairs $(1-212$ in table 2$)$ with known precise dates of pupal emergence, and dates of non-accidental death, the mean is 576 days (1.6 years). For five similar males kept in pairs (111-203 in table 3) a mean life span was 790 days (2.2 years). However, the oldest male lived more than 1526 days ( 4.2 years).

Age of fertility was reached in nine females (paired with older males when the females left their pupal cell) at the mean age of 31.5 days after eclosion from the pupa, if the questionable figures of 51, 63, and 130 days are deleted from computation. Data are too few to determine the age of fertility in males, but is it probably similar to that of the females. Likewise, although data are too few (tables 2 and 3 ) to determine commonness of the phenomenon, at least some individual males and 
Table 2. Data in days for longevity and reproductive characteristics of female $P$. hirtus of unknown age, and roughly grouped categories of young females and old females. Females 208 and 212 not listed. Both produced their first egg at 31 days of adult life, and these figures were also used in calculating a mean time of reaching reproductive maturity.

\begin{tabular}{|c|c|c|c|c|}
\hline & age at & oduction & $\begin{array}{l}\text { days } \\
\text { between }\end{array}$ & $\begin{array}{l}\text { days between } \\
\text { which eggs }\end{array}$ \\
\hline umb & death & no. eggs & eggs & were laid \\
\hline
\end{tabular}

Females of unknown age

$2 \mathrm{a} \quad 325+\quad 45$

$4 a \quad 767+$

61

$6 a \quad 420+$

31

$8 \mathrm{a} \quad 142+$

29

$10 \mathrm{a} \quad 353+-380+47$

$12 \mathrm{a} \quad 189+\quad 23$

$14 \mathrm{a} \quad 342+$

32

$16 \mathrm{a} \quad 342+$

40

$18 \mathrm{a} \quad 351+$

42

$20 \mathrm{a} \quad 342+$

29

'Young' Females

$\begin{array}{rlrr}1 & 307 & 41 & 168 \\ 6 & 551-683 & 72 & 154 \\ 102 & 743 & 46 & 169 \\ 104 & 875 & 31 & 124 \\ 108 & 191-323 & 17 & 38 \\ 112 & & 18 & 160 \\ 150 & 244 & 65 & 145 \\ 206 & 451 & 56 & 202 \\ 209 & & 44 & 160\end{array}$

'Old' Females

$\begin{array}{rlrr}102 & 743 & 164 & 330 \\ 104 & 875 & 221 & 431 \\ 154 & 651 & 6 & 48 \\ 173 & 842 & 16 & 76 \\ 204 & 532 & 86 & 300 \\ 205 & 896 & 16 & 70 \\ 210 & 476-608 & 74 & 136 \\ 211 & 950 & 104 & 199\end{array}$

168

$\begin{array}{rrrr}296 & 6.6 & 27+ & 323+ \\ 145 & 2.4 & 4+ & 149+ \\ 287 & 9.3 & 132+ & 419+ \\ 87 & 3.0 & 4+ & 91+ \\ 252 & 5.4 & 35+ & 287+ \\ 122 & 5.3 & 9+ & 131+ \\ 320 & 10.0 & 8+ & 328+ \\ 314 & 7.8 & 13+ & 327+ \\ 324 & 7.7 & 4+ & 328+ \\ 335 & 11.6 & 4+ & 339+\end{array}$

$\begin{array}{llll}4.1 & 38 & 206 & 37\end{array}$

$\begin{array}{llll}2.1 & 39 & 193 & 23\end{array}$

$\begin{array}{llll}3.7 & 30 & 199 & 35\end{array}$

$\begin{array}{llll}4.0 & 79 & 203 & 51\end{array}$

$\begin{array}{llll}2.2 & 152 & 190 & 130\end{array}$

$\begin{array}{llll}8.9 & 29 & 189 & 29\end{array}$

$\begin{array}{llll}2.2 & 80 & 225 & 63\end{array}$

$\begin{array}{llll}3.6 & 48 & 250 & 28\end{array}$

$\begin{array}{llll}3.6 & 54 & 214 & 37\end{array}$

$2.0 \quad 360 \quad 690$

$2.0 \quad 375 \quad 806$

$8.0 \quad 395 \quad 443$

$4.6 \quad 739 \quad 815$

$3.5 \quad 212 \quad 512$

$4.4 \quad 774 \quad 844$

$1.8 \quad 340 \quad 476$

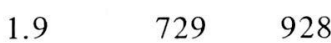


Table 3. Data in days for longevity and notes on reproductive activity in adult males of $P$. hirtus of unknown and known ages.

$\begin{array}{rcl}\begin{aligned} \text { culture } \\ \text { number }\end{aligned} & \text { life span } & \text { notes } \\ 1 \mathrm{a} & 408+ & \\ \text { 3a } & 192+ & \text { fertile until } 30 \text { days before death } \\ 5 \mathrm{a} & 648+-750+ & \\ 7 \mathrm{a} & 648+-750+ & \\ 9 \mathrm{a} & 353+-380+ & \\ 11 \mathrm{a} & 392+ & \\ 13 \mathrm{a} & 1080+ & \text { fertile at death } \\ 15 \mathrm{a} & 1050+ & \text { fertile at death } \\ 17 \mathrm{a} & 648+-750+ & \\ 19 \mathrm{a} & 924+ & \text { fertile at death } \\ 4 & 19 & \text { first fertile at } 19 \text { days } \\ 106 & 198-330 & \text { first fertile at } 161 \text { days } \\ 111 & 328 & \text { continually with female but no offspring } \\ 115 & 198-330 & \text { first fertile at } 42 \text { days } \\ 119 & 642 & \\ 163 & 472 & \text { no reproduction for last 35 days of life } \\ 200 & 1526 & \\ 201 & 982+ & \text { accidental death } \\ 202 & 1477 & \\ 203 & 1034 & \\ & & \end{array}$

females were reproductively active through their full life span of several years. However, infertility also existed in some pairs of beetles. For instance, one female produced seven larvae hatching from eggs in 10 days after the death of her male, and then no more. A new male placed with her resulted in no more larvae in the five months preceding the death of the male. In addition to beetle pairs which produce no fertile eggs, some fertile pairs may become infertile. Female 4a which had produced 61 eggs in 145 days, produced no eggs from day 398 of captivity until death at day 767 . Female 154 produced no eggs in the 70 days preceding her death at day 651 .

Because of time limitations, no attempt was made to pursue the above observations and to determine answers to various questions such as the relationship of reproductive rate to food quality or quantity (the effect of finding a carrion bonanza in a cave), the relationship of female feeding rate and reproductive rate, or the relationship of reproductive rate and longevity, or of the amount of individual 
sterility, or of the percentages of reproductive incompatibilities between randomly paired beetles (some mating choice may be available in caves). These research problems are available, and some data has been obtained for some Bathysciini (Deleurance-Glaçon, 1963a).

In beetles raised from immature stages in the laboratory, egg production seems to be slightly less frequent in young females and more frequent in old females, but the difference is not significant. Nine females in a comparatively younger age category of 29 to 250 days laid eggs with a mean frequency of one every 3.8 days. Eight females in a comparatively older age category of from 212 to 927 days of age laid eggs with a mean frequency of one every 3.5 days.

Females have the ability to store sperm and produce viable eggs for about one and one half months after copulation. This was learned from two sets of females taken from community culture, and placed in isolation away from males. A set of five females produced fertile eggs for up to 40 days after isolation. A set of 10 females produced their last fertile eggs 55 days after isolation. After these periods, eggs were laid in small numbers, but did not hatch. This ability to store sperm for a time after copulation is of advantage for an insect which may need to distribute itself widely and at low densities to locate and take advantage of occasional food bonanzas.

\section{DISCUSSION}

Unfortunately, direct comparison of life cycle characteristics of $P$. hirtus and the European Bathysciini is not possible because the two sets of data were obtained at different temperatures. The Bathysciini, reared at $9^{\circ} \mathrm{C}$, have longer immature life cycles, as a result of the cooler rearing conditions, and a different $\mathrm{Q}_{10}$ developmental rate. However, some subjective somparison is possible. P. hirtus, in adult morphology and possession of three larval instars, is most like the Bathysciola schioedti, an eyeless, wingless inhabitant of moss in forests in the Pyrenees and a troglophile on guano in caves.

B. schioedti, at $9^{\circ} \mathrm{C}$, has an egg duration of 56 days. Each of the first two larval instars feeds for about two weeks and then sits without feeding in a molting cell. The third instar also feeds for two weeks but then spends a month as a non-feeding larva, and then enters a molting cell for 102 days. In all, 210 days are spent as a larva, with only 42 days as a feeding larva. The pupal stage lasts 59 days (Deleurance-Glaçon, 1963a).

It is possible to attempt to eliminate the effects of the different rearing temperatures on the developmental rates of immature $P$. hirtus and B. schioedti by using the $\mathrm{Q}_{10}$ approximation. Assuming a $\mathrm{Q}_{10}$ of 2 , we might then expect the development of $B$. schioedti at $9^{\circ} \mathrm{C}$ to be 0.825 times as long as the developmental rate at $12.5^{\circ} \mathrm{C}$. Calculations from these assumptions show that $B$. schioedti, if reared at $12.5^{\circ} \mathrm{C}$ would still be expected to have longer developmental times than $P$. hirtus and that these would be about 2.5 times longer egg duration, about 4 times the total larval life span, and about 1.5 times longer pupal stage. Thus, B. schioedti has 
a comparatively increased developmental time and a slower absolute growth rate, which are indications of it being more cave specialized (Poulson, 1963) than $P$. hirtus.

This "greater cave specialization" in a troglophilic species when compared to a troglobitic species in a different tribe in the same family is undoubtedly a reflection of different evolutionary histories of the two groups over a long time span. The Bathysciini probably experienced considerable life cycle evolution and modification when they were still more of an epigean group than now. Then, these epigean life cycle modifications successfully preadapted (in an acceptable evolutionary sense, Peck, 1973: 44) the group for its later and very successful occupation of caves, which is now their major habitat.

In summary, within the Bathysciini, B. schioedti is considered to represent a primitive condition of life cycle characteristics. The more specialized and troglobitic Bathysciini have fewer but larger eggs, longer egg hatching times, few instars, less larval feeding time, less time spent as a larva, and longer pupation time. Thus, in the light of this subjective and comparative background, $P$. hirtus possesses a life cycle which is modified from that of many epigean insects, but is not at all specialized when compared to a relatively unspecialized European troglophilic Bathysciine like $B$. schoedti. These differences have resulted probably from more life cycle evolution in epigean than in cave environments.

So far, the data on the life cycle of $P$. hirtus sits in a comparative vacuum. No other American Catopid life cycle data are published. And where P. hirtus fits in a series of epigean, troglophilic, and troglobitic of Ptomaphagus remains to be documented. However, data have been obtained at $15^{\circ} \mathrm{C}$ for six Ptomaphagus species, representing these three levels of cave specialization, and will be presented in a later paper.

\section{ACKNOWLEDGEMENTS}

Field and laboratory work was partially supported by NSF grants GB 3167 and GB 7346 to the Evolutionary Biology Committee, Harvard University, Professor Reed C. Rollins, principal investigator; and systematic operating grants from the National Research Council of Canada to Dr. H. F. Howden and myself. The administration of the National Park Service at Mammoth Cave National Park, Kentucky, is thanked for its aid and cooperation in allowing study and sampling in some of the caves under their protection. T. L. Poulson provided comments on an early draft of the manuscript.

\section{SUMMARY}

Ptomaphagus hirtus has been successfully kept in laboratory culture at $12.5^{\circ} \mathrm{C}$ with food in surplus at all times. Eggs hatched in 18.5 days. Three larval instars were present, which had a total larval life span of 42 days. The pupal stage lasted 32 
days. Adult males and adult females had average life spans of 2.2 years and 1.6 years respectively. Maximum adult longevity was 4.2 years. Females reached reproductive maturity a month after eclosion, young and old females produced one egg every 3.5 and 3.8 days respectively, and were reproductively active for as long as 2.5 years. Compared to European cave catopid beetles, this is a primitive or ummodified life cycle.

\section{RESUME}

Ptomaphagus hirtus a été maintenu, avec succès, en élevage au laboratoire, à $12,5^{\circ} \mathrm{C}$ et avec une nourriture constamment en excédent. Les oeufs éclosent au bout de 18,5 jours. Il y a trois stades larvaires, qui couvrent la vie larvaire en 42 jours. Le stade pupe dure 32 jours. Les adultes ont une durée de vie moyenne de 2,2 années pour les mâles et de 1,6 pour les femelles. Le longévité maximum de l'adulte est de 4,2 années. Les femelles arrivent à maturité sexuelle un mois après l'éclosion; les jeunes femelles pondent un oeuf environ tous les 3,5 jours, les femelles âgées tous les 3,8 jours; leur activité reproductrice s'étend jusqu'à 2,5 années. Ce cycle biologique, comparé à celui des Coléoptères Catopides cavernicoles d'Europe, semble être primitif ou ne pas avoir évolué.

\section{REFERENCES}

Barr, T. C., Jr., and R. A. Kuehne. 1971. Ecological studies in the Mammoth Cave system of Kentucky. II. The ecosystem. Ann. Speleologie, 26: 47-96.

Deleurance-Glaçon, S. 1963a. Recherches sur les coléoptères troglobies de la sous-famille des Bathysciinae. Ann. Sci. Natur. (Zool.), ser. 12, 5: 1-172.

1963b. Contribution à l'étude des coléoptères cavernicoles de sous-famille des Trechinae. Ann. Spéléologie, 18: 227-265.

1964. Recherches sur les coléoptères troglobies de la sous-famille des Bathysciinae. Ann. Spéléologie, 19: 573-580.

Gounot, A. M. 1967. La microflore des limons argileux souterrains: son activité productrice dans la biocénose cavernicole. Ann. Ann. Spéléologie, 22: 587-645.

Laneyrie, R. 1967. Nouvelle classification des Bathysciinae (Coléoptères Catopidae). Ann. Spéléogie, 22: 587-645.

1969. Addenda et corrigenda à la "Nouvelle Classification des Bathysciinae." Ann. SpSpéléologie, 24: 733-736.

Peck, S. B. 1973. A systematic revision and the evolutionary biology of Ptomaphagus (Adelops) beetles of North America (Coleoptera: Leiodidae: Catopinae), with emphasis on cave-inhabiting species. Bull. Mus. Comparative Zool., 145: 29-162.

Poulson, T. L. 1963. Animals in aquatic environments: animals in caves, in Dill, D. B., ed. Handbook of Physiology, sec. 4, "Adaptations to the environment", Amer. Physiol. Soc., Washington, ch. 47, pp. 749-771.

Vandel, A. 1965. Biospeleology. New York: Pergamon Press, Inc. 524 pp. 